\title{
IMPLEMENTASI PENDIDIKAN KARAKTER DALAM PERKULIAHAN PERPAJAKAN PADA MAHASISWA JURUSAN PENDIDIKAN AKUNTANSI FISE UNIVERSITAS NEGERI YOGYAKARTA
}

\author{
Oleh : \\ Isroah", \\ Sukanti ${ }^{2}$, \\ Ani Widayati ${ }^{3}$
}

\begin{abstract}
Abstrak
Penelitian ini bertujuan untuk mengetahui (1). Model pemberian tugas mandiri dalam perkuliahan Perpajakan Mampu Mendorong Sikap dan Perilaku Jujur pada Mahasiswa Jurusan Pendidikan Akuntansi FISE UNY (2) Model kerja praktik (simulasi) berkelompok dalam Perkuliahan Perpajakan Mampu Mendorong Sikap/Perilaku Tanggung Jawab pada Mahasiswa Jurusan Pendidikan Akuntansi FISE UNY.

Penelitian ini merupakan penelitian tindakan klas ( class room action research) yang dirancang dalam dua putaran/siklus meliputi kegiatan (a). Perencanaan tindakan (b). Pelaksanaan tindakan (c). Observasi (d). Refleksi. Teknik pengumpulan data dengan observasi, angket, dan dokumentasi. Teknik analisis data yang digunakan adalah analisis deskriptif.

Hasil penelitian menunjukkan ahwa (1) Metode pemberikan tugas mandiri dalam perkuliahan perpajakan belum mampu mendorong sikap dan perilaku jujur pada mahasiswa Jurusan pendiidkan Akuntansi FISE UNY. Hal ini terbukti pada siklus pertama bahwa mahasiswa mengerjakan dan mengumpulkan tugas mandiri dengan menyalin pekerjaan teman, mahasiswa tidak mengerjakan tugasnya sendiri artinya tidak bertanggung jawab pada tugas yang dibebankannya. (2). Metode kerja praktik (simulasi) berkelompok dalam perkuliahan perpajakan mampu mendorong sikap/perilaku jujur dan tanggung jawab padai mahasiswa Jurusan pendiidkan Akuntansi FISE UNY. Berdasarkan angket tertutup yang diberikan diketahui bahwa sebagian besar mahasiswa (100\%) memiliki nilai kejujuran akademik dan non akademik yang bagus (rata-rata nilai 90) dan memilki tanggung jawab akademik dan non akademik yang tinggi (rata-rata nilai 85).
\end{abstract}

\section{A. Pendahuluan}

Daerah Istimewa Yogyakarta telah dikenal sebagai kota pendidikan, kota seni dan budaya serta kota wisata. Sebagai kota pendidikan tentunya banyak dikunjungi pelajar dan mahasiswa yang menuntut ilmu di Yogya karta dengan harapan setelah menyelesaikan pendidikannya mereka dapat bekerja (mendapat pekerjaan) sesuai dengan harapannya.

Jumlah pengangguran di Yogyakarta terus meningkat di setiap tahunnya. Saat ini jumlah pengangguran di Yogyakarta mencapai 151.570 orang, meliputi

\footnotetext{
${ }^{1}$ Staf Pengajar Jurusan P. Akuntansi Fakultas Ekononi Universitas Negeri Yogyakarta

${ }^{2}$ Staf Pengajar Jurusan P. Akuntansi Fakultas Ekononi Universitas Negeri Yogyakarta

${ }^{3}$ Staf Pengajar Jurusan P. Akuntansi Fakultas Ekononi Universitas Negeri Yogyakarta
} 
$73.193(48 \%)$ laki laki dan 73.378 (52\%) perempuan. Jika dilihat dari tingkat pendidikannya, pengangguran berasal dari lulusan SD 2,63\%, SLTP 15,24\%, SLTA $62,11 \%$ Diploma diantaranya dan Sarjana 20,02\%. (Direktorat Kelembagaan Dirjen DIKTI:2009). Bahkan menurut Kepala Dinas Tenaga Kerja dan Transmigrasi Provinsi D.I.Yogyakarta menyatakan bahwa salah satu penyebab tingginya pengangguran adalah akibat kondisi rendahnya kualitas dan produktivitas tenaga kerja.

Rendahnya kualitas tenaga kerja dapat disebabkan oleh beberapa faktor diantaranya berupa ketidaksinkronan/kesenjangan program antara lembaga pendidikan (termasuk Perguruan Tinggi) dengan kebutuhan pasar tenaga kerja. Kesenjangan tersebut disebabkan oleh sistem pembelajaran yang diterapkan di Perguruan Tinggi saat ini masih berorientasi pada hard skill yakni menyiapkan mahasiswa yang cerdas keilmuan, cepat lulus dan segera mendapat pekerjaan. Sementara itu pembelajaran yang berorientasi pada kreativitas, inovatif, mandiri, jujur, disiplin, kerja keras, toleransi dan saling menghargai (pembelajaran berorientasi karakter) belum banyak diterapkan.

Pendidikan berorientasi karakter saat ini sudah waktunya untuk diimplementasikan dengan serius, karena ada indikasi tentang penurunan kualitas produk pendidikan yang ditandai dengan menurunnya nilai-nilai etika, moral dan kejujuran pada sebagian besar mahasiswa. Selain itu terjadi kemunduran kepribadian sehingga tidak bisa hidup di masyarakat dikarenakan tidak bisa menyesuaikan diri dengan lingkungannya.

Pola pembelajaran yang berientasi pada karakter ini nantinya mampu menstimulasi mahasiswa sejak dini sehingga akan terbentuk watak yang mengandung nilai-nilai kemuliaan sehingga akan terwujud sumber daya insani yang berkualitas. Hal ini sesuai dengan program pemerintah yakni telah meluncurkan "pembangunan karakter untuk mendorong kesadaran dan pentingnya membangun peradaban bangsa". (Koran Tempo, 29 April 2010)

Mata kuliah perpajakan merupakan mata kuliah keterampilan berkarya yang wajib ditempuh oleh mahasiswa Jurusan Pendidikan Akuntansi Fakultas Ilmu Sosial dan Ekonomi. Berdasarkan hasil observasi, interview, dan analisis terhadap hasil kuis/ujian pada kegiatan pembelajaran matakuliah Perpajakan di masa lalu, diperoleh kenyataan bahwa: (1). Sebagian besar mahasiswa merasa kesulitan dalam mempelajari materi yang diajarkan (2) Mahasiswa pasif, kurang percaya diri, kurang jujur dan kurang tanggung jawab yakni saat mengerjakan tugas dengancara menyalin milik teman (3). Hasil kuis/ujian menunjukkan nilai yang masih rendah.

Fenomena ini memerlukan perhatian dan harus segera diatasi agar aktivitas dan hasil pembelajaran peserta didik dalam matakuliah Perpajakan dapat ditingkatkan sehingga dapat tercapai lulusan yang kompeten, jujur dan bertanggung jawab. Pengajar memperoleh gambaran bahwa permasalahan kesulitan dalam mempelajari materi perpajakan yang dihadapi mahasiswa adalah: (1). Pada analisis permasalahan perpajakan yang memerlukan kekuatan logika, dan diperlukan tingkat kejujuran yang tinggi (2). Matakuliah perpajakan merupakan matakuliah yang statutoris dan dinamis yakni harus mematuhi peraturan yang ditetapkan dalam Undang Undang Perpajakan, Keputusan Menteri Keuangan, maupun Keputusan Dirjen Pajak yang acap kali 
berubah seiring perubahan situasi dan kondisi/perkembang masyarakat. Oleh karena itu diperlukan tanggung jawab yang kuat.

Tujuan penelitian ini adalah untuk mengetahui: (1). Model Pemberian Tugas Mandiri dalam Perkuliahan Perpajakan Mampu Mendorong Sikap/Perilaku Jujur Mahasiswa Jurusan Pendidikan Akuntansi FISE UNY (2). Model kerja praktik (simulasi) berkelompok dalam Perkuliahan Perpajakan Mampu Mendorong Sikap/Perilaku Tanggung Jawab Mahasiswa Jurusan Pendidikan Akuntansi FISE UNY.

Sampai saat ini masih dipercaya bahwa keberhasilan pendidikan bagi anak ditentukan oleh kemampuannya membaca dan berhitung pada usia dini. Hal tersebut tidak benar, menurut Ratna Megawangi (2010) bahwa justru kematangan emosi yang terbentuk yang akan menentukan kesuksesan anak. Banyak contoh di sekitar kita yang menunjukkan bahwa orang yang memiliki kecerdasan otak saja, memiliki gelar tinggi belum tentu sukses berkiprah di dunia kerja dan sukses di masyarakat. Daniel Goleman dalam Richard A. Bowell (2004) menggambarkan bahwa "yang paling cerdas di antara kita dapat terjerembab pada hasrat yang tak terkekang dan impuls yang tak dikendalikan, orang dengan IQ tinggi dapat menjadi pilot yang buruk dalam kehidupan pribadi mereka. Salah satu rahasia umum psikologi adalah ketidakmampuan relatif skor-skor perguruan tinggi, skor IQ, meski itu semua populer, untuk memprediksi dengan pasti siapa yang akan berhasil dalam kehidupan pribadi...."

Keberhasilan seorang anak, siswa, mahasiswa, seseorang di sekolah, di tempat kerja dan di masyarakat tidak hanya ditentukan oleh kecerdasan otak saja. Bahkan Daniel Goleman dalam Richard A. Bowell (2004) menyatakan bahwa "IQ paling-paling menyumbang $20 \%$ pada faktor-faktor yang menentukan sukses dan $80 \%$ ditentukan oleh kecerdasan emosi”.

Menurut Covey dalam Ari Ginanjar (2005:42) dinyatakan bahwa "kecerdasan emosi adalah kemampuan untuk merasa". Oleh karena itu kecerdasan emosi sangat berkaitan erat dengan suara hati meliputi kejujuran, percaya diri, amanah, inisiatif, empati, motivasi, optimis, ketangguhan, dan kemampuan beradaptasi. Menurut peneliti, komponen tersebut dapat dikategorikan sebagai karakter.

Sebenarnya kecerdasan emosi (termasuk kecedasan spiritual) lebih banyak dideteksi dari fakta kehancuran moral/akhlak. Hal tersebut dikarenakan oleh ketidakmampuan dalam mengelola emosi sebaik-baiknya yang menyebabkan tidak mampu mengatasi konflik emosi yang dialami sehingga lebih dikuasi perasaan negatif dari pada perasaan positif.

elanjutnya Thomas Loqkona dalam Ratna Megawangi (2010) mengungkapkan bahwa ada sepuluh tanda-tanda jaman yang harus diwaspadai karena jika tanda-tanda itu sudah ada maka itu berarti semua bangsa sedang menuju ke jurang kehancuran. Tanda-tanda itu adalah (1) meningkatnya kekerasan di kalangan remaja, (2) penggunaan bahasa dan kata-kata yang memburuk, (3) pengaruh peer group yang kuat dalam tindak kekerasan, (4) meningkatnya perilaku merusak diri seperti penggunaan narkoba, alkohol dan seks bebas, (5) semakin kaburnya pedoman moral baik dan buruk, (6) menurunnya etos kerja (7) semakin rendahnya rasa hormat pada orang tua dan 
guru, (8) rendahnya tanggung jawab individu dan warga negara, (9) membudayakan ketidakjujuran dan (10) adanya rasa saling curiga dan kebencian diantara sesama.

Oleh karenanya, saat ini sudah waktunya untuk bertindak/praktik nyata dalam membenahi, menata dan mengelola emosi secara bersamaan dengan praktik mengajar baik di rumah, di sekolah/kampus maupun di masyarakat. Pembelajaran yang ada saat ini sudah waktunya untuk diberikan muatan yang berisi tentang pembangunan karakter.

Selanjutnya dalam data US Development Healt and Human Service tahun 2000 dijelaskan bahwa "terdapat 13 faktor penunjang keberhasilan, sepuluh diantaranya adalah kualitas karakter seseorang dan tiga lainnya berkaitan dengan faktor kecerdasan (IQ). Ke 13 faktor tersebut adalah (1) jujur dan dapat diandalkan, (2) bisa dipercaya dan tepat waktu, (3) bisa menyesuaikan diri dengan orang lain, (4) bisa bekerjasama dengan atasan, (5) bisa menerima dan menjalankan kewajiban, (6) mempunyai motivasi kuat dan untuk terus berjalan dan meningkatkan kualitas diri, (7) berfikir bahwa dirinya berharga, (8) bisa berkomunikasi dan mendengarkan secara efektif, (9) bisa bekerja mandiri dengan kontrol terbatas, (10) dapat menyelesaikan masalah pribadi dan profesinya. Sedangkan tiga terakhir yang berkaitan dengan IQ adalah (1) mempunyai kemampuan dasar/kecerdasan, (2) bisa membaca dengan pemahaman memadai, (3) mengerti dasar/dasar matematika/berhitung.

Hal tersebut menunjukkan betapa pentingnya pendidikan karakter bagi setiap manusia. Karena keberhassilan ataupun kegagalan seseorang dalam masyarakat lebih banyak ditentukan oleh kualitas karakter dari pada kecerdasannya

\section{a. Pembelajaran Terintegrasi dengan Pendidikan Karakter}

Dalam menanggapi tingkat keragaman budaya bangsa, sebagai kekuatan, penciptaan dan pengkajian Universitas Negeri Yogyakarta mewajibkan dirinya untuk memperluas dan memeratakan akses melalui pendidikan, penelitian, dan pelayanan kepada masyarakat yang menjadi bagian dari tanggung jawab sosial. Di samping itu tuntutan masyarakat semakin meningkat, sehingga UNY berkewajiban untuk menghasilkan lulusan yang berkualitas tinggi dan mampu mandiri dalam pergaulan masyarakat dunia, berperan aktif dalam mengendalikan perubahan seni dan budaya, menghasilkan karya yang mampu mendorong peningkatan keunggulan bangsa, serta berdampak terhadap pertumbuhan ekonomi dalam menunjang pembangunan bangsa.

"Universitas Negeri Yogyakarta juga bertekad untuk meningkatkan perannya dalam pengembangan pendidikan karakter menuju universitas kelas dunia" (Media Indonesia, 21 April 2010). Tekad UNY telah mulai dibuktikan dengan berbenah diri diantaranya mulai dari pembenahan kurikulum yang memasukkan mata kuliah Pendidikan Karakter sebagai mata kuliah wajib bagi mahasiswa angkatan 2009.

Melalui pendidikan karakter sebagai upaya untuk membenahi, menata dan mengelola emosi, hal ini bukanlah pekerjaan yang dibatasi oleh waktu. Ilmu untuk melesatkan kecerdasan emosional dalam membangun karakter bukanlah ilmu matamatis ataupun sebagai ilmu 
bisnis yang harus dilalui secara bertahap dimana sebelum menerapkan lanjutan harus diterapkan bab sebelumnya. Artinya dalam menerapkan pendidikan karakter ini harus dibenahi dan ditata dahulu pengajarnya (guru/dosen) baru diijinkan untuk mengajar. Dengan cara tersebut akan memakan waktu yang lama dikarenakan guru/dosen masih perlu pelatihan dan menerapkan watak pribadinya yang bagus, setelah itu baru diperkenankan untuk mengajar pendidikan karakter kepada siswa/mahasiswanya.

Pembelajaran yang berlangsung selama ini adalah dengan mengajarkan sesuatu yang bersifat olah pikir atau kognitif saja yang berarti baru mengolah keterampilan otak kiri saja. Sementara itu yang berkaitan dengan masalah hati dan otak kanan belum banyak disentuh. Dalam pembelajaran yang bermuatan dengan pembangunan karakter (caracter building) diterapkan secara bersamaan dengan pembangunan atau pembenahan karakter yang dimiliki oleh pendidik selama ini. Artinya guru/dosen mulai membenahi, menata dan mengelola dirinya dengan baik sekaligus berusaha membelajarkan cara membenahi, menata dan mengelola diri kepada siswa/mahasiswa.

Menurut Foster dalam Doni Kusuma (2010) menyebutkan ada empat ciri dasar dalam pendidikan karakter yaitu: Pertama, keteraturan interior dimana setiap tindakan diukur berdasar hierarki nilai artinya nilai menjadi pedoman. Kedua, Koherensi yang memberi keberanian, membuat seseorang teguh pada prinsip, tidak mudah terombang-ambing pada situasi baru atau takut risiko. Koherensi merupakan dasar membangun rasa percaya satu sama lain. Tidak adanya koherensi meruntuhkan kredibilitas seseorang. Ketiga, otonomi. Seseorang menginternalisasikan aturan dari luar sampai menjadi nilai-nilai bagi pribadinya. Hal ini dapat dilihat melalui penilaian atas keputusan pribadi tanpa terpengaruh atau desakan pihak lain. Keempat, keteguhan dan kesetiaan. Keteguhan merupakan daya tahan seseorang guna mengingini apa yang dipandang baik. Kesetiaan merupakan dasar bagi penghormatan atau komitmen yang dipilih.

Selanjutnya Ratna Megawangi (2010) menyakatan tentang penerapan konsep pendidikan holistik berbasis karakter yang mencakup sembilan pilar karakter yaitu (1) Cinta Tuhan dan segenap ciptaannya (2) Tanggung jawab, kedisiplinan dan kemandirian, (3) kejujuran/amanah dan arif, (4) hormat dan santun, (5) dermawan, suka menolong dan gotong-royong/kerjasama, (6) percaya diri, kreatif, dan pekerja keras, (7) kepemimpinan dan keadilan, (8) baik dan rendah hati, (9) toleransi, kedamaian dan kesatuan.

Berdasarkan atas pendapat tersebut, maka peneliti mempunyai ide bahwa Pendidikan Karakter dapat diimplementasikan dengan menyatu pada setiap mata kuliah yang ada, sehingga setiap guru/dosen berkewajiban untuk menerapkan pembangunan karakter bagi siswa/mahasiswanya sekaligus guru/dosen juga membenahi diri dalam membangun karakter dirinya. 


\section{b. Implementasi Pendidikan Karakter dalam Perkuliahan Perpajakan}

Berdasarkan Peraturan Pemerintah No. 60/1999 pasal 13 ayat (1) Penyelenggaraan pendidikan tinggi dilaksanakan dalam programprogram studi atas dasar kurikulum yang disusun oleh masing-masing perguruan tinggi; dan ayat (2) Kurikulum sebagaimana yang dimaksud pada ayat (1) berpedoman pada kurikulum yang berlaku secara nasional (Kurnas) dengan penjelasan bahwa Kurnas merupakan rambu-rambu untuk menjamin mutu dan kemampuan penyelenggaraan dalam bentuk proporsi terhadap kelompok mata kuliah. Pada saat Kurnas sudah terbentuk, penyelenggaraan Kurnas tersebut ditangani oleh program studi yang bersangkutan. Dalam hal ini, program studi akan menentukan kurikulum sesuai dengan kelompok-kelompok mata kuliah.

Penyelenggaraan perguruan tinggi berkaitan dengan aspek kultural dan aspek struktural. Permasalahan kultural meliputi demokratisasi equility dan equality antar bidang ilmu, kesempatan belajar, mutu, akses sumber daya, penyelenggaraan pendidikan, dan lain-lain, relevansi pendidikan, akuntabilitas, profesionalisme dan efisiensi ketergunaan yang rendah, adanya kecenderungan uniformitas, dan ketergantungan pada pemerintah sehingga mengurangi kebebasan ilmu dan mimbar akademis, kejujuran dan ketulusan penyelenggaraan. Sedangkan permasalahan struktural penyelenggaraan pendidikan meliputi tatanan SDM, pendidik, lingkungan akademis, sistem pendanaan, tatanan lalu lintas pertukaran mahasiswa, tatanan keserasian penyelenggaraan pendidikan antar lembaga, dan ketersediaan fasilitas. Sejalan dengan hal di atas menurut PP No. 25/2000 pasal (3) butir 11 memuat, kewenangan pemerintah di bidang pendidikan dan kebudayaan; penetapan standar materi pelajaran pokok kurikulum yang berlaku secara nasional; penetapan persyaratan pedoman pembiayaan penyelenggaraan pendidikan; penetapan persyaratan penerimaan, perpindahan dan sertifikasi mahasiswa; dan pengaturan dan pengembangan pendidikan tinggi, pendidikan jarak jauh, serta pengaturan sekolah (perguruan tinggi) internasional.

Pembelajaran perpajakan dirancang dengan tujuan agar mahasiswa aktif, kreatif dan mendorong mahasiswa untuk mampu membangun konsep serta mempraktikkan tentang apa yang telah dialami atau diketahui. Selain Rencana Perkuliahan (RP) sebagai desain pembelajaran, maka perkuliahan perpajakan juga dilengkapi dengan bahan ajar yang disusun peneliti. Bahan ajar ini disusun karena adanya kelemahan dari buku perpajakan yang ada di masyarakat belum mampu mengukuti perubahan peraturan yang ditetapkan dalam undang undang perpajakan maupun Keputusan Menteri Keuangan dan Keputusan Dirjen Pajak.

Dalam pembelajaran ini juga dirancang sistem penilaian yang digunakan yakni formulir tentang sistem penilaian yang berisi tentang identitas mata kuliah, deskripsi mata kuliah, estándar kompetensi mata kuliah, skema verja dan sistim penilaian. Dalam penilaian tersebut tidak hanya bersifat kognitif saja namun juga mengamati tentang afektifnya terutama tentang kejujuran dan tanggung jawab. 
Pembelajaran ini juga memungkinkan mahasiswa lebih aktif melalui berbagai teknik pembelajaran yang terfokus pada mahasiswa seperti exercise/penyelesaian soal, tugas pribadi dan tugas kelompok. Dengan demikian aktivitas mahasiswa dapat tergali dan muncul, hal ini sesuai dengan pembelajaran yang bersifat Student Center Learning (SCL) yakni pembelajaran yang berpusat pada mahasiswa. Dengan cara ini mahasiswa akan memperoleh pengalaman untuk mengaplikasikan dalam pemecahan masalah di lapangan/dunia usaha/masyarakat berdasarkan pengalaman yang dimiliki.

Sistem penilaian yang diterapkan memungkinkan untuk dilakukan penilaian yang lebih objektif dan reliable terhadap hal-hal yang sifatnya subjektif. Sistem penilaian yang tepat memberikan informasi yang lebih baik dalam rangka peningkatan proses pembelajaran, oleh karena itu sistem penilaian tersebut diharapkan dapat meningkatkan kompetensi mahasiswa pada matakuliah Perpajakan.

\section{Hipotesis Tindakan} berikut:

Berdasarkan kajian teori tersebut dapat disusun hipotesis tindakan

(1). Model Pemberian Tugas Mandiri dalam Perkuliahan Perpajakan Mampu Mendorong Sikap/Perilaku Jujur Mahasiswa Jurusan Pendidikan Akuntansi FISE UNY (2) Model kerja praktik (simulasi) berkelompok dalam Perkuliahan Perpajakan Mampu Mendorong Sikap/Perilaku Tanggung Jawab Mahasiswa Jurusan Pendidikan Akuntansi FISE UNY.

\section{B. Metode Penelitian}

Penelitian ini merupakan penelitian tindakan klas (class room action research) dengan menerapkan pendidikan karakter yang teritegrasi dalam perkuliahan perpajakan, siklus yang dirancang dalam dua putaran/siklus yang dilakukan secara intensif dan dianalisis dengan cermat. Adapun siklusnya meliputi kegiatan:

a. Perencanaan tindakan;

b. Pelaksanaan tindakan

c. Observasi/monitoring

d. Refleksi.

Pada putaran pertama dengan pemberian tugas mandiri, variasi penyelesaian soal (exercise) dan diskusi dengan bimbingan dosen, dimana mahasiswa telah diberikan bahan ajar sebagai sumber belajarnya. Implementasi pembelajaran ini diobservasi dengan seksama selama proses pembelajaran berlangsung dan dievaluasi melaui tes (evaluasi hasil) sebagai alat deteksi keberhasilan model selanjutnya disusun refleksi. Jika model tersebut sudah berhasil maka dilanjutkan pada putaran kedua.

Pada putaran kedua ini model pembelajaran yang diterapkan adalah dengan kerja praktik (simulasi) berkelompok yang dilakukan yang terdiri dari empat atau lima mahasiswa tiap-tiap kelompok. Mahasiswa ditugaskan untuk penyelesaian (kasus hipotetis) yang berkaitan dengan cara menghitung, memperhitungkan, pembayaran dan penyampaian laporan (mengisian Surat 
Pemberitahuan/SPT). Hasil dari praktik dilaporkan dan dipresentasikan dalam diskusi kelompok. Melalui praktik ini akan selalu diingat dan terekam pada diri mahasiswa sehingga mereka memiliki persepsi, sikap dan perilaku yang sesuai dengan bidang perpajakan. Tingkat keberhasilan dari model ini dapat dilihat dari presentasi tugas dan selanjutnya dilengkapi dengan evaluasi hasil berupa tes. Adapun siklus yang digunakan adalah sesuai dengan model Kemmis dan Mc. Taggar.

Sesuai dengan tujuan penelitian ini, maka teknik pengumpulan data yang digunakan adalah: (1). Observasi partisipatif yang dilakukan oleh seorang peneliti sebagai pengajar mata kuliah Perpajakan (sekaligus peneliti) dan dua orang peneliti lainnya sebagai pengamat dan perekan data selama pembelajaran Perpajakan berlangsung. (2). Angket tentang nilai kejujuran dan tanggung jawab (3) Dokumentasi dari hasil kerja mahasiswa

\section{Instrumen Penelitian}

Instrumen yang diperlukan dalam penelitian sejalan dengan prosedur dan langkah penelitian tindakan. Instrumen untuk mengukur keberhasilan tindakan dapat dipahami dari dua sisi yaitu sisi proses dan sisi hal yang diamati. Yakni (1) dari sisi proses dan (2) dari sisi hal yang diamati. Dari sisi proses (bagan alirnya), instrumen dalam penelitian ini dapat menjangkau masalah yang berkaitan dengan input (kondisi awal), proses (saat berlangsung), dan output (hasil).

\section{a. Instrumen untuk input}

Instrumen untuk input dapat dikembangkan dari hal-hal yang menjadi akar masalah beserta pendukungnya. Misalnya: akar masalah adalah bekal awal berupa tingkat kejujuran dan tanggung jawab peserta didik yang dianggap kurang. Dalam hal ini tes bekal awal dapat menjadi instrumen yang tepat. Di samping itu, mungkin diperlukan pula instrumen pendukung yang mengarah pada pemberdayaan tindakan yang akan dilakukan, misalnya: format peta kelas dalam kondisi awal, buku teks dalam kondisi awal dan lainlainnya.

\section{b. Instrumen untuk proses}

Instrumen yang digunakan pada saat proses berlangsung berkaitan erat dengan tindakan yang dipilih untuk dilakukan yaitu kejujuran dan tanggung jawab. Dalam tahap ini banyak format yang dapat digunakan. Akan tetapi, format yang digunakan hendaknya yang sesuai dengan tindakan yang dipilih.

\section{c. Instrumen untuk output}

Adapun instrumen untuk output berkaitan erat dengan evaluasi pencapaian hasil berdasarkan kriteria yang telah ditetapkan. Misalnya: nilai 75 ditetapkan sebagai ambang batas peningkatan (pada saat dilaksanakan tes bekal awal, nilai peserta didik berkisar pada angka 50), maka pencapaian hasil yang belum sampai pada angka 75 perlu untuk dilakukan tindakan lagi (pada siklus berikutnya).

Pengamatan merupakan alat yang terbukti efektif untuk mempelajari tentang metode dan strategi yang diimplementasikan di kelas, misalnya, tentang organisasi kelas, respon siswa terhadap 
lingkungan kelas, dsb. Salah satu bentuk instrumen pengamatan adalah catatan anekdotal (anecdotal record). Catatan anekdotal memfokuskan pada hal-hal spesifik yang terjadi di dalam kelas atau catatan tentang aktivitas belajar siswa dalam pembelajaran. Catatan anekdotal mencatat kejadian di dalam kelas secara informal dalam bentuk naratif. Sejauh mungkin, catatan itu memuat deskripsi rinci dan lugas peristiwa yang terjadi di kelas. Catatan anekdotal tidak mempersyaratkan pengamat memperoleh latihan secara khusus. Suatu catatan anekdotal yang baik setidaknya memiliki empat ciri, yaitu (1) pengamat harus mengamati keseluruhan sekuensi peristiwa yang terjadi di kelas (2) tujuan, batas waktu dan rambu-rambu pengamatan jelas (3) hasil pengamatan dicatat lengkap dan hati-hati, dan( 4) pengamatan harus dilakukan secara objektif.

Instrumen untuk memperoleh data berupa:

1). Soal tes digunakan untuk mengetahui kinerja mahasiswa

2). Lembar observasi dan angket digunakan untuk mengetahui tentang perilaku/sikap jujur daan tanggung jawab serta persepsi mahasiswa tentang matakuliah Perpajakan guna pemberian masukan tentang pelaksanaan tindakan.

3). Catatan untuk merekam data selama pembelajaran/pelaksanaan tindakan berlangsung.

\section{Teknik Analisis Data}

Setelah data terkumpul selanjutnya dikelompok dalam dua macam data yaitu data kuantitatif berupa hasil unjuk kerja mahasiswa dan data kualitatif berupa hasil catatan observasi selanjutnya dianalisis berupa analisis deskriptif dengan langkah-langkah: (1). Analisis data observasi yaitu data observasi yang telah diperoleh dihitung kemudian di persentase, dengan demikian dapat diketahui peningkatan yang telah dicapai. (2) Analisis data angket yaitu, setiap butir angket dikelompokkan sesuai dengan aspek yang diamati, kemudian dihitung skornya. Jumlah skor yang diperoleh dipersentase dan dikategorikan sesuai dengan kualifikasi hasil angket tentang kejujuran dan tanggung jawab.(3) Analisis hasil tes yaitu Hasil tes/kuis pada akhir siklus dihitung nilai rata-ratanya selanjutnya digunakan sebagai dasar keberhasilan tindakan yang berkaitan dengan kompetensi/hasil belajar.

\section{Hasil Penelitian dan Pembahasan}

\section{Siklus Pertama}

Perencanaan tindakan meliputi kegiatan: (a). Menyusun RPP dan bahan ajar (b). Menyiapkan lembar observasi tentang kejujuran dan tanggung jawab serta aktivitas lainnya. (c) Menyiapkan angket tentang respon pembelajaran, kejujuran dan tanggung jawab.(d) Menyiapkan soal tes/kuis (e) Menyiapkan catatan/rekaman peristiwa di kelas

Pelaksanaan tindakan meliputi kegiatan: (a) Setiap perkuliahan diawali dengan salam dan menyampaikan standar kompetensi yang harus dicapai yaitu tentang Mendeskripsikan Pajak Penghasilan Umum (b) Mahasiswa telah mempunyai bahan ajar sebagai panduan untuk belajar 
dan menyelesaikan tugas. (c) Mahasiswa diberi tugas untuk mencari materi/download tentang Norma Penghitungan Pajak Penghasilan. (d). Mahasiswa mempelajari materi untuk didiskusikan, dengan cara seorang mahasiswa maju untuk menyampaikan materi/tugas mandiri dalam waktu 10 sampai 15 menit. Mahasiswa lain diberi kesempatan untuk bertanya atau memberi masukan/saran. (d) Dilakukan tes/kuis dan mengisi angket.

Observasi (a) Observasi dilakukan untuk mengamati aktivitas mahasiswa, yaitu pada saat diskusi berlangsung. Secara sukarela mahasiswa maju untuk menyampaikan temuan/tugas sebanyak 5 mahasiswa (10\%) dan yang mengajukan pertanyaan/memberi masukan/menambahkan sebanyak 15 mahasiswa (30\%) (b). Berdasarkan angket yang diberikan diketahui bahwa sebagian besar mahasiswa (60\%) dalam mengerjakan tugas masih menyalin/mengkopi dari teman (tidak download sendiri) (c)Berdasarkan nilai kuis diketahui bahwa rata-rata nilai 69.38

Refleksi (a) Pada siklus pertama ini nilai kejujuran belum nampak yakni mahasiswa mengerjakan tugas mandiri dengan cara menyalin pekerjaan teman. Hal ini menunjukkan bahwa nilai tanggung jawab mahasiswa juga belum ada yakni tidak mengerjakan tugasnya sendiri artinya tidak bertanggung jawab pada tugas yang dibebankannya.(b) Mahasiswa mengikuti kuliah dengan tertib dan bersemangat tetapi ratarata nilai kuis masih relatif rendah sehingga perlu peningkatan dalam aspek penguasaan materi dengan memperbanyak latihan (sesuai dengan saran mahasiswa)

\section{Siklus Kedua}

Perencanaan tindakan meliputi kegiatan: (a) Menyiapkan lembar observasi tentang kejujuran dan tanggung jawab serta aktivitas lainnya (b).Menyiapkan angket tentang respon pembelajaran, kejujuran dan tanggung jawab (c) .Menyiapkan bahan praktik/simulasi untuk tugas kelompok (d) Menyiapkan catatan/rekaman peristiwa di kelas

Pelaksanaan tindakan, (a) Setiap perkuliahan diawali dengan salama dan menyampaikan standar kompetensi yang harus dicapai yaitu tentang Menerapkan Penghitungan PPh pasal 21/26 (b) Mahasiswa telah mempunyai bahan ajar sebagai panduan untuk belajar dan menyelesaikan tugas (c) Mahasiswa diberi tugas kelompok berupa bahan praktik penghitungan PPh pasal 21 dan pengisian SPT yakni (a). Mahasiswa mengerjakan secara berkelompok yang terdiri 4 - 5 orang untuk menghitung pajak dan mengisi SPT setelah itu menyampaikan materi/tugas mandiri dalam waktu 10 sampai 15 menit. Mahasiswa lain diberi kesempatan untuk bertanya atau memberi masukan/saran. (b). dilakukan tes/kuis dan mengisi angket.

Observasi dilakukan untuk mengamati aktivitas mahasiswa, yaitu pada saat presentasi kelompok berlangsung. Semua mahasiswa berkesempatan maju untuk menjelaskan hasil penghitungan pajak yang menjadi tugasnya. Berdasarkan angket terbuka yang diberikan, maka dapat disimpulkan bahwa mahasiswa memperoleh jawaban benar dengan 
hasil kerja kelompok yaitu dapat bertanya kepada teman yang sudah manguasai.Hasil observasi ini diperkuat dengan angket yang menunjukkan hasil sebagai berikut: (a) Berdasarkan angket tertutup yang diberikan, dapat diketahui bahwa sebagian besar mahasiswa (100\%) memiliki nilai kejujuran akademik dan non akademik yang bagus (ratarata nilai 90) dan memilki tanggung jawab akademik dan non akademik yang tinggi (rata-rata nilai 85). (b) Berdasarkan nilai kuis diketahui bahwa rata-rata nilai 83.88

Refleksi (a) dengan menerapkan kerja praktik (simulasi) berkelompok ini mahasiswa dapat lebih menguasai materi karena jika tidak jelas akan diberi penjelasan oleh temannya. Mereka lebih percaya diri dan bertanggung jawab untuk maju di depan kelas dalam menyajikan pekerjaannya. Berdasarkan angket penilaian diri sendiri tentang kejujuran dan tanggung jawab, maka sebagian besar mahasiswa memilki kejujuran dan tanggung jawab yang tinggi baik secara akademik dan non akademik serta kompetensi mahasiswa dapat tercapai dengan indikasi nilai rata-rata 83,88

\section{Penutup}

\section{Kesimpulan}

Berdasarkan hasil penelitian ini dapat disimpulkan bahwa:

1. Metode pemberikan tugas mandiri dalam perkuliahan perpajakan belum mampu mendorong sikap dan perilaku jujur bagi mahasiswa Jurusan pendiidkan Akuntansi FISE UNY. Hal ini terbukti pada siklus pertama bahwa mahasiswa mengerjakan dan mengumpulkan tugas mandiri dengan menyalin pekerjaan teman, mahasiswa tidak mengerjakan tugasnya sendiri artinya tidak bertanggung jawab pada tugas yang dibebankannya.

2. Metode kerja praktik (simulasi) berkelompok dalam perkuliahan perpajakan mampu mendorong sikap/perilaku jujur dan tanggung jawab bagi mahasiswa Jurusan pendiidkan Akuntansi FISE UNY. Berdasarkan angket tertutup yang diberikan diketahui bahwa sebagian besar mahasiswa (100\%) memiliki nilai kejujuran akademik dan non akademik yang bagus (rata-rata nilai 90) dan memilki tanggung jawab akademik dan non akademik yang tinggi (rata-rata nilai 85).

\section{E. Daftar Pustaka}

Ari Ginanjar Agustin. (2005). ESQ (Emotional Spiritual Quotient). Jakarta: Arga.

Badrun Kartowagiran, (2003) Supervisi dan Evaluasi Keterlaksanaan KBK, Unpublished. Yogyakarta

Dadan Supratan, (2001) Konstruktivistik dalam Pembelajaran, Unpublished. Yogyakarta

Dahar R. (1999) Teori- Teori Belajar, Erlangga. Jakarta 
Dirjen Dikti, (2004) Draft Tanya Jawab Seputar Proses Pembelajaran di Perguruan Tinggi, Diknas, Jakarta.

--------- (2004) Draft Tanya Jawab Seputar Kurikulum Berbasi Kompetensi di Perguruan Tinggi, Diknas, Jakarta

Dirjen Dikmenum, (1999) Bahan Pelatihan Penelitian Tindakan, Depdikbud, Jakarta

Doni Kusuma, (2010) Pendidikan Karakter, Kompas Cyber Media

Endang Komara (2003), Pembelajaran Aktif di Perguruan Tinggi, www.geocities.com/endangkomara, Bandung.

Harlen W. (1992) The Teaching of Scienc, David Fulton Publisher, London

Hysyam Zaini, Bermawy Munthe, Sekar Ayu Ariyani, (2004) Strategi Pembelajaran Aktif. CTSD IAIN, Yogyakarta.

Muhammad Muhyidin. (2006). ESQ Power for Better Life. Yogyakarta: Tunas Publishing.

Richard A. Bowell. (2006). The 7 Steps of Spiritual Quotient. Jakarta: PT. Bhauana Ilmu Populer .

Suparman, Atwi. (ed.). (1997). Model-Model Pembelajaran Interaktif, STIA LAN Press, Jakarta.

Suwarsih Madya, (1994), Panduan Penelitian Tindakan, Lemlit IKIP Yogyakarta, Yogyakarta.

Syaiful Bahri dan Aswan Zain. (1977). Strategi Belajar Mengajar. Penerbit Rineka Cipta. Jakarta.

Undang-undang Republik Indonesia Nomor 2 Tahun 2003 Tentang Sistem Pendidikan Nasional. 